\title{
Re-Interpretasi Utopisme "Palembang Emas Darussalam" melalui Penyediaan Ruang Terbuka Hijau di Kota Palembang
}

\author{
Raegen Harahap ${ }^{1}$ \& Siti Anisyah² \\ 1,2Program Studi Ilmu Politik \\ Universitas Islam Negeri Raden Fatah, Palembang \\ Email: raegenharahap_uin@radenfatah.ac.id \\ sitianisyah_uin@radenfatah.ac.id
}

\begin{abstract}
Abstrak
Wacana pembangunan wilayah perkotaan berbasis ekologi, dengan menerapkan pembangunan berbasis penyediaan Ruang Terbuka Hijau (RTH) telah lama menjadi agenda global, nasional dan lokal. Namun, dewasa ini masih banyak belum sepenuhnya mampu memenuhi kebutuhan itu karena terkendala berbagai aspek. Dalam penelitian ini, bertujuan untuk mengetahui bagaimana realitas dan upaya penyediaan Ruang Terbuka Hijau (RTH) di kota Palembang untuk mewujudkan minimal 30\%. Penelitian tersebut juga berbentuk desain penelitian dengan metode kualitatif deskriptif dengan menggunakan pendekatan studi kasus dan studi kepustakaan. Adapun temuan yang didapatkan dalam penelitian setidaknya dalam dua dimensi yaitu (1) bahwa realitas dan eksistensial penyediaan ruang terbuka hijau (RTH) masih memiliki banyak menemui tantangan, baik dari laju pembangunan, laju pertambahan penduduk, dan konsistensi dalam menindaklanjuti para pelanggar konversi atau alih fungsi lahan; (2) bahwa pelaksanaan implementasi kebijakan masih berada pada tahap administratif dan pembagian para teknisi lapangan, dan masih banyak tantangan dalam profesionalitas dan keterbatasan dukungan sarana dan prasarana di lapangan. Oleh karena itu, pemerintah kota Palembang belum sepenuhnya dalam melaksanakan dalam kebijakannya dalam pemenuhan wilayah daerah perkotaan yang elok sesuai dengan utopisme yang dicanangkan pada tahun 2012 lalu.
\end{abstract}

Kata kunci: Implementasi kebijakan, RTH, kota Palembang

\begin{abstract}
The discourse of ecology-based urban development, by implementing green open space (RTH) based development has long been a global, national and local agenda. However, today there are still many regions, not yet fully able to meet these needs due to various aspects. In this study, it aims to determine how the reality and efforts to provide green open space $(R T H)$ in the city of Palembang to realize a minimum of $30 \%$. This research is also in the form of a research design with descriptive qualitative methods using a case study approach and literature study. The findings obtained in the research are at least in two dimensions, namely (1), that the existential reality of the provision of green open space $(R T H)$ still has many challenges, both from the rate of development, the rate of population growth, and consistency in following up on conversion or transfer offenders. land function; (2), whereas the implementation of the policy is still at the administrative stage and division of field technicians, and there are still many challenges in professionalism and limited support for facilities and infrastructure in the field. Therefore, the government of Palembang city has not fully implemented its policies in fulfilling beautiful urban areas in accordance with the utopianism that was declared in 2012.
\end{abstract}

Keywords: implementation policy, Green Open Space, Palembang City. 


\section{PENDAHULUAN}

Kota-kota besar di Indonesia, umumnya tidak dapat menghindari dampak negatif dari pesatnya pembangunan dan lajunya pertambahan populasi penduduk terhadap ketersediaan lahan terbuka. Badan Pusat Statistik (BPS) merilis laporan bahwa pada tahun 2010, angka pertumbuhan penduduk daerah perkotaan berkisar $49,8 \%$, dan melonjak naik sebesar 66,6\% tahun 2035 (Bappena 2013; Sholihah and Sabarisman 2018). Sementara itu, intensitas aktifitas pembangunan mengalami perkembangan begitu pesat. Semua wilayah lahan kosong diperuntukkan untuk ruang terbuka semakin lama kian menurun. Ketidakseimbangan ketersediaan lahan diakibatkan oleh konversi-konversi lahan menjadi pembangunan. Ruang kosong di berbagai sudut kota "disulap" menjadi fasilitas perkantoran, perhotelan, pemerintahan, pertokoan, perumahan, dan fasilitas sarana dan prasarana transporasi. Konsekuensinya, luasan lahan yang ada di kota-kota besar mengalami penurunan. Pada tahun 1970, luasan berkisar sebanyak 35\%, namun pada dekade ini hanya tersisa 10\% lagi (Miranti et al. 2011).

Berdasarkan hasil Musyawarah Rencana Pembangunan (Musrenbang) Nasional pada 30 April 2018, kota Palembang di bidang pembangunan terus mengalami perkembangan (Syahrul Ansari dan Sadam Maulana 2018). Dalam konteks itu, sebagai teras ibu kota provinsi Sumatera Selatan, Kota Palembang, bukan saja berkembang di bidang pembangunan melainkan juga lonjakan populasi. Hanya berselang 3 tahun, populasi penduduk mengalami laju kenaikan signifikan dari jumlah 1.580 .517 di tahun 2015 mencapai 1.643 .488 jiwa pada tahun 2018 (Badan Pusat Statistik Palembang 2018), dengan luas lahan hanya berkisar $5 \%$ atau sekitar $35.855 \mathrm{Ha}$, dengan eksistensi ruang terbuka hanya 3.645 Ha (Mogabay.co.id 2018). Merujuk aturan standar peraturan pemerintah Nomor 26/2007 tentang penataan ruang harus sebanyak $30 \%$, (20\% untuk publik dan $10 \%$ pribadi). Jika dikalkulasikan antara luas wilayah Kota Palembang saat ini hanya $5 \%$ dengan standard 30\%, maka setidaknya masih membutuhkan sekitar $10.756 \mathrm{Ha}$. Oleh karena itu, kota Palembang masih krisis lahan terbuka sangat signifikan dalam menyediakan ruang terbuka hijau (RTH).

Komitmen pemerintah Kota Palembang dalam merekonstruksi permasalahan ini, telah lama ditetapkan dalam Peraturan pemerintah Nomor 15 Tahun 2012 tentang RTRW (Ruang Terbuka, Ruang Wilayah) 2012-2030 (Walikota Palembang 2012). Bahkan, keseriusan itu dipertegas kembali dalam visi-misi walikota Harnojoyo-Fitriani baik pada periode (2012-2017) hingga masa pemerintahan 20182023. Dalam visi-misi itu, dengan jelas menyatakan mewujudkan pembangunan infrastruktur perkotaan yang terpadu, merata berkeadilan, berkelanjutan dan berwawasan lingkungan yang berbasis teknologi dan informasi (jdih.palembang.go.id 2018).

Salah satu solusi tepat dalam mewujudkan ruang terbuka hijau dilakukan dengan cara memperbanyak atau membangun kembali taman kota. Keberadaan taman di dalam kawasan perkotaan sangat bermanfaat sebagai tempat bertemu dengan alam. karena taman bukan hanya sebagai miniatur kota, akan tetapi sebagai penyimpan energi untuk tempat rekreasi dalam mereduksi stress dari "hiruk-pikuk" aktivitas masyarakat perkotaan (Dwihatmojo 2010; Sholihah and Sabarisman 2018). Bahkan, lebih dari itu, kekurangan ruang terbuka hijau dalam lingkungan kota pada faktanya memberikan efek negatif pada aspek keseharan mental orang-orang yang hidup di dalamnya dan begitupun sebaliknya (Yusmawar 2016). 
Telah banyak tulisan, kajian, dan telaah ilmiah di berbagai penelitian dengan disiplin dan perspektif khas masing-masing dalam membahas konsep ruang terbuka hijau di Indonesia. Akan tetapi, dari sekian banyak penelitian dilakukan, konsep ruang terbuka hijau lebih didominasi pada tulisan optimalisasi, dan dampak eksistensi ruang terbuka hijau terhadap wilayah permukiman, sosial, hukum. Seperti misalnya, studi di kota Makassar oleh Rakhmatsyah, Hasanuddin, dan Tahir (2015), mengungkapkan bahwa dampak ketersediaan ruang terbuka hijau akan membawa dampak positif terhadap pencegahan banjir, mereduksi temperatur kota, menjadi sarana berolahraga dan berbagai macam kebermanfaaatan lainnya yang diperuntukkan kepada publik. Studi yang dilakukan oleh Sholihah dan Sabarisman (2018), mengungkapkan bahwa dalam tingkat kompleksitas kehidupan masyarakat di wilayah perkotaan, dan terpenuhinya hajat kesejahteraan sosialnya dapat dipenuhi dengan menyediakan ruang terbuka hijau di lingkungan kota. Dalam memenuhi kebutuhan tersebut, pemerintah perlu melakukan pendekatan dan penguatan pemenuhan melalui penguatan payung hukum yang jelas sehingga kebijakan dapat diimplementasikan dengan optimal. Riset ruang terbuka hijau di DKI Jakarta yang dilakukan oleh Prakoso dan Herdiansyah (2019) menyatakan bahwa dalam mewujudkan penyediaan ruang terbuka hijau dengan standar aturan $30 \%$ dapat tercapai dengan cara menggandeng para pemangku kepentingan, partisipasi masyakarat dan pengetatan aturan.

Belum banyaknya, penelitian yang menjelaskan tentang upaya penyediaan ruang terbuka hijau ditinjau dari konsep utopisme kepala daerah. Kajian tersebut diperkuat dengan visi-misi pemerintah kota Palembang mulai periode 2012-2017 hingga periode sekarang. Namun, masih banyak fakta di lapangan yang menunjukkan bahwa pemerintah kota Palembang masih memiliki kendala dan tantangan dalam menyediaan ruang terbuka hijau sesuai standar yang telah ditetapkan. Atas hal demikian, tulisan ini hendak mengisi ruang kosong itu. Maka, tulisan ini ingin menguraikan sejauh mana komitmen dan keseriusan pemerintah kota Palembang dalam menciptakan pola pembangunan ruang terbuka hijau ditinjau dari implementasi kebijakan? Dalam menjawab pertanyaan tersebut, tulisan akan dibagi kepada tiga (3) kelompok. Pertama, realitas dan eksistensi ruang terbuka hijau di kota Palembang. Kedua, sejauh mana proses pelaksanaan dan implementasi kebijakan tersebut di lapangan?, dan terakhir mengkonklusikan seluruh permasalahan.

\section{METODE PENELITIAN}

Fokus kajian pada penelitian ini bermodus kualitatif deskriptif dengan rancangan studi menggunakan prosedur case study (studi kasus). Konsep tersebut dipilih sebagai tujuan dalam rangka untuk menguraikan arti dan makna baik secara eksplit maupun implisit terhadap fenomena (case) masalah yang sedang diteliti, sekaligus berupaya menguraikan mengenai kausalitas fenomena terkait. Disamping sebagai prosedur dalam kajian ini, studi kasus juga dapat menjadi metode dalam mengeleborasi secara detail dan menelaah secara komprehensif dengan fenomena yang sedang diteliti, dalam metode deskriptif ditambah dengan prosedur lainnya. Dengan menggunakan prosedur kajian ini, diharapkan mampu menyingkap "penutup" dalam mengkaji, menelaah, mengungkapkan, dan mengelaborasi secara detail objek kajian yang diteliti. Selain itu, penelitian ini juga menggunakan library 
research (studi kepustakaan) terutama berkaitan dengan berbagai referensi untuk keperluan data dan menunjang keaslian penelitian, seperti Mogabay, Walhi, Perda kota Palembang dan sebagainya.

Peneliti mendeskripsikan suatu fenomena dengan berdasarkan pada pandangan partisipan riset serta hasil observasi yang mendalam. Selain menggunkan observasi, cara lain yang digunakan oleh peneliti adalah wawancara pada saat pengumpulan data. Cara mengolah data dengan metode deskriptif adalah data yang telah terkumpul, diolah kemudian dianalisis dengan menggunakan narasi tertentu yang diambil dari data lapangan.

\section{KERANGKA PEMIKIRAN}

Menelaah dan mengkaji sebuah implementasi kebijakan dalam aspek pemenuhan kebijakan secara efektif, harus ditinjau berdasarkan ukuran atau faktor standar tertentu. Dengan adanya ukuran ataupun faktor tersebut suatu kebijakan dalam aspek pengimplementasiannya dapat dianalisis akan sejauh proses pelaksaan, masalah yang menjadi kendala dan faktor yang mempengaruhi keberhasilan dari kebijakan-kebijakan yang ditetapkan. Dalam hal itu, George C. Edward telah memformulasikan dalam empat faktor penting dalam meninjau berjalannya dari sebuah kebijakan.

1. Communication transmission, clarify and consistency (proses komunikasi yang disampaikan dengan jelas dan konsisten)

2. Resources: staff information, authority facilities (terdapat sumberdaya yang didukung oleh staf, informasi, kewenangan maupun fasilitas yang memadai)

3. Dispositin: incentive, staffing (terdapat penunjukan yang jelas mengenai pemberian insentif dan dukungan staf.

4. Bureautatic Structure: standard operating procedures, fragmentation (terdapat sistem birokrasi yang memiliki prosedur dan standar kerja yang memadai.

Dalam fomulasi yang dikembangkan oleh George C. Edwards, mengatakan bahwa tingkat akurasi dari sebuah kebijakan memiliki tahapan-tahapan jelas, model pembentukan terarah, dan sekaligus memproyeksikan kendala-kendala yang dapat mempengaruhi aspek-aspek lainnya. Jika demikian, akan menghasilkan suatu kebijakan yang tepat. Akan tetapi, meskipun tahapan-tahapan telah tersusun dengan baik, namun, jika aspek pengimplementasian terutama pihak pelaksana di lapangan, maka dapat dipastikan bahwa kebijakan yang akan dilaksanakan tidak dapat berjalan dengan baik (Edwards 1980).

Dalam konsep itu, George C. Edwards berusaha merekomendasikan dengan menitikberatkan pada empat faktor krusial guna teraplikasikannya dari setiap kebijakan. Pada realitasnya, dalam mengimplementasikan sebuah kebijakan, semua aspek saling memiliki keterkaitan dan saling mempengaruhi satu sama lain, sehingga membutuhkan pola kebijakan yang terus-menerus dan simultan. Dalam konteks itu pula, semua aspek yang mempengaruhi dari implementasi kebijakan harus dipetakan, dirumuskan dan dibahas secara terperinci dari segala aspek terkait. Karena pada umumnya, pengimplementasian kebijakan bukanlah statis, dan alamiah akan tetapi berpola dinamis, yang berkaitan satu aspek dengan aspek lainnya, dan variabel dengan variabel lainnya. Dengan itu, setiap proses pelaksaan kebijakan, saling memeliki ketergantungan dan keterikatan yang tidak bisa 
dilepaskan satu dengan yang lain. Atas dasar konsep implementasi kebijakan tersebut, setiap pelaksanaan kebijakan yang dilakukan bukan hanya menyangkut pihak pemerintah sebagai pembuat kebijakan saja, akan tetapi berkaitan juga dengan pihak-pihak pemangku kepentingan yang tekait lainnya baik di bidang sosial, politik dan ekonomi yang kemudian menghasilkan kebijakan yang efektif dan terimplementasikan dengan baik.

\section{HASIL DAN PEMBAHASAN}

\section{Realitas Eksistensial Ruang Terbuka Hijau (RTH) di Kota Palembang}

Isu lingkungan hidup terutama berkaitan dengan penyediaan ruang terbuka hijau (RTH) telah banyak dikampanyekan oleh berbagai masyarakat baik di tingkat global, nasional dan maupun lokal. Kajian yang dilakukan oleh Heidt and Neef (2007), wacana pembangunan kota berbasis ekologi (ecological cities) telah banyak memberikan perhatian kepada konsep pembangunan dengan memperhatikan unsur ekologi. Wacana demikian sebagai wujud nyata dari persoalan yang dewasa ini dihadapi di kehidupan perkotaan. Oleh karena, diperlukan kebijakan yang jelas dan arah manajemen terukur beserta payung hukum dalam mengelola wilayah perkotaan (Suweda 2011)

Kajian yang dilakukan oleh Nirwono Joga (2013) mengenai luasan wilayah untuk ruang terbuka hijau di kota besar yang ada di Indonesia belum semuanya memenuhi standar aturan pemerintah sebanyak 30\%. Bahkan sampai saat ini, optimalisasi keberadaan ruang terbuka hijau masih belum sesuai ekspektasi karena masih banyak permasalahan-permasalahan yang menyebabkan keterpenuhan harapan tersebut.

Provinsi Sumatera Selatan, terutama daerah kota Palembang memiliki "gestur" persoalan lingkungan sangat paralel dengan aktivitas pembangunan baik oleh pemerintah maupun masyarakat. Perubahan lingkungan di kota Palembang, secara empiris begitu rasional disebabkan oleh intensitas dalam aspek pembangunan perkantoran, perumahan dan pemerintahan yang begitu masif. Dengan kata lain, aktifitas dalam aspek pembangunan merubah secara drastis lingkungan di kota Palembang (Yenrizal dan Izomiddin 2018).

Sebagaimana data yang dirilis oleh Walhi tahun 2005 kota Palembang memiliki luas rawa sebanyak $200 \mathrm{Ha}$ (Walhisumsel.com 2010). Namun, tidak untuk saat ini, karena terjadi aktifitas penimbunan rawa yang dialokasikan kepada perumahan dan toko secara terus menerus. Sebanyak $150 \mathrm{Ha}$ hilang dan hanya tersisa $50 \mathrm{Ha}$ atau 58,34 $\mathrm{km}^{2}$ hingga saat ini (Mogabay.co.id 28/02). Bahkan, dari sisa luas rawa saat ini, bukanlah terbentuk secara alamiah, melainkan telah mengalami konservasi sebanyak $2.106 \mathrm{Ha}$, reklamasi $917 \mathrm{Ha}$ dan budidaya seluas 2.811 Ha (Mogabay.co.id 2014).

Demi mencapai gelar kota metropolitan bertarap internasional, ambisi pemerintah kota Palembang sudah terlihat sejak tahun 2004. Penyulapan lahan, yang dahulunya diperuntukkan untuk pertanian, sekarang berubah menjadi bangunan fisik menjulang tinggi. Berbagai bangunan insfrastruktur, gedung perkantoran dan perhotelan terus menggeliat. Konsekuensinya adalah meskipun kota Palembang telah mencapai derajat metropolitan, yang ditinjau dari populasi penduduk, pertumbuhan ekonomi dan sarana dan prasarana penunjang lainnya, namun, "miskin" dalam aspek pembangunan berbasis (ecology) lingkungan (Rijal 
Syamsu 2017).

Tabel 1. Luas ruang terbuka hijau di Kota Palembang pada Dinas Pertamanan Tahun 2012-2015

\begin{tabular}{|c|c|c|c|c|c|c|c|}
\hline \multirow{4}{*}{ No } & \multirow{4}{*}{$\begin{array}{c}\text { Jenis } \\
\text { Ruang } \\
\text { Terbuka }\end{array}$} & \multicolumn{6}{|c|}{ Tahun } \\
\hline & & \multirow{2}{*}{\multicolumn{2}{|c|}{2013}} & \multicolumn{2}{|c|}{2014} & \multicolumn{2}{|c|}{2015} \\
\hline & & & & \multicolumn{2}{|c|}{ Luas } & \multicolumn{2}{|c|}{ Luas } \\
\hline & & $\mathbf{M}^{2}$ & $\mathrm{Ha}$ & $\mathbf{M}^{2}$ & $\mathrm{Ha}$ & $\mathbf{M}^{2}$ & $\mathrm{Ha}$ \\
\hline 1 & $\begin{array}{l}\text { Taman } \\
\text { Kota }\end{array}$ & $238,621,8$ & 23,86 & $248,322,8$ & 24,83 & $249,038,8$ & 24,90 \\
\hline 2 & $\begin{array}{l}\text { Jalur } \\
\text { Hijau }\end{array}$ & $9,823,680$ & 982,37 & $10,021,220$ & 1002,14 & $10,496,960$ & 1049,70 \\
\hline 3 & $\begin{array}{l}\text { Hutan } \\
\text { Kota }\end{array}$ & $12,150,000$ & 1,215 & $12,150,000$ & 1,215 & $12,1500,000$ & 1,215 \\
\hline \multicolumn{2}{|c|}{ Total Luas } & $22,212,302$ & 2221,23 & $22,419,763$ & 2241,98 & $22,895,997$ & 2289,60 \\
\hline \multicolumn{2}{|c|}{$\begin{array}{l}\text { Persentase dari } \\
\text { luas kota } \\
\text { Palembang: } \\
40061 \text { a }\end{array}$} & \multicolumn{2}{|c|}{$5,5446 \%$} & \multicolumn{2}{|c|}{$5,5964 \%$} & \multicolumn{2}{|c|}{$5,7153 \%$} \\
\hline
\end{tabular}

Sumber: Dinas Penerangan Jalan Pertamanan dan Pemakaman (DPJPP) Kota Palembang

Sebagaimana dikatakan oleh Kepala Bidang Pertamanan pada Dinas Penerangan Jalan Pertamanan dan Pemakaman, Keberadaan ruang terbuka hijau di Kota Palembang, masih sekitar 10\% (Sary and Kamil 2017). Dari laporan yang dirilis Walhi Sumatera Selatan pada tahun 2019, luas wilayah untuk peruntukan ruang terbuka hijau hanya sekitar $3.801 \mathrm{Ha}$, yang semestinya harus disediakan seluas $12.018 \mathrm{Ha}$ sesuai dengan aturan pemerintah nomor 26 Tahun 2007 Tentang Penataan Ruang (Walhisumsel.com 2010). Bahkan lebih dari itu, jumlah taman di kota Palembang sampai tahun 2019 hanya sebanyak 322 unit taman dengan luas 249.036,8 m2.

Tabel 2. Jumlah serta luas taman setiap kecamatan di Kota Palembang tahun 2017

\begin{tabular}{|c|l|c|c|}
\hline Nomor & \multicolumn{1}{|c|}{ Kecamatan } & Jumlah Taman & Luas area $\left.\mathbf{( M}^{2}\right)$ \\
\hline 1. & llir Timur I & 55 & 44.270 \\
\hline 2. & llir Timur II & 21 & 8.850 \\
\hline 3. & Ilir Barat II & 14 & 31.7015 \\
\hline 4. & Sematang Borang & 1 & 300 \\
\hline 5. & llir Barat I & 63 & 187.7474 \\
\hline 6. & Gandus & 10 & 10.800 \\
\hline 7. & Bukit Kecil & 57 & 148.218 \\
\hline 8. & Seberang Ulu I & 70 & 199.550 \\
\hline 9. & Kertapati & 20 & 6.235 \\
\hline 10. & Alang-Alang Lebar & 18 & 22.550 \\
\hline 11. & Plaju & 1 & 137 \\
\hline 12. & Sukarame & 44 & 87.475 \\
\hline 13. & Seberang Ulu II & 5 & 1.723 \\
\hline 14. & Sako & 5 & 1.723 \\
\hline 15. & Kemuning & 16 & $12.215,3$ \\
\hline & & & \\
\hline
\end{tabular}




\begin{tabular}{|c|c|c|c|}
\hline 16. & Kalidoni & 12 & 63.587 \\
\hline \multicolumn{2}{|c|}{ Jumlah/Total } & 413 & 939.075 .8 \\
\hline
\end{tabular}

Sumber: Dinas Penerangan Jalan Pertamanan dan Pemakaman (DPJPP) Kota Palembang

Pesatnya pembangunan dan praktik investor menjadi tantangan paling krusial pemerintah kota Palembang dalam menyediakan ruang terbuka hijau. Kawasan perkotaan merupakan tempat kombinasi dari berbagai kegiatan penduduk yang didominasi oleh pekerjaan pada sektor perekonomian, pemerintahan dan jasa. Sektor tersebut menyumbang terjadinya konservasi lahan terhadap pembangunan perhotelan, perkantoran, mall dan kantor-kantor lainnya. Sebagaimana yang penjelaskan dari Harry Emirza (25/06/2020) sebagai kepala pembibitan pertamanan dalam penelitian ini mengatakan, "lajunya pembangunan sehingga menghambat dalam menyediakan ruang terbuka hijau".

Iklim perubahan di kota Palembang secara tidak langsung menyebabkan ketidaktersediaan lahan memadai yang diperuntukkan ruang terbuka hijau. Meskipun regulasi penyediaan ruang terbuka hijau di Kota Palembang telah diatur begitu jelas dalam draf kebijakan. Terutama, ketika berhadapan dengan para investor yang mengkonvernsi ruang terbuka hijau untuk pembangunan seperti mall dan gedung perkantoran. Pemberlakuan ataupun pemberian sanksi terhadap mereka (investor) tidak begitu optimal. Oleh karena itu, upaya dalam menyediakan ruang terbuka hijau di kota Palembang belum sepenuhnya terlaksanakan dengan maksimal. Dalam hal itu, WALHI menuturkan bahwa saat ini penegakan hukum terkait masalah lingkungan masih lemah, dibuktikan masih banyaknya warga masyarakat Kota Palembang yang tidak merawat dan menjaga ruang terbuka hijau yang sudah ada.

Hal tersebut sangat berkorelasi langsung dengan tingkat kesadaran masyarakat terhadap pemenuhan ruang terbuka hijau. Masyarakat hanya berpartisipasi dalam aspek perencanaan pembangunan saja. Pada akhirnya mengakibatkan terhadap rendahnya tingkat berpatisipasi kelompok masyarakat dalam menjaga, menanam pohon. Ketidakonsistenan juga berpengaruh kepada para aktivis peduli lingkungan dalam mendukung program pemerintah dalam menjaga taman kota, hutan kota dan jalur hijau (RTH). Oleh karena itu, keterbatasan lahan untuk mewujudkan ruang terbuka hijau, bukan saja disebabkan oleh lajunya pembangunan, melainkan juga komitmen nyata dan bentuk perhatian pemerintah dalam memprioritaskan pembangunan berbasis ekologi dan lingkungan. Padahal, sebagaimana yang disebutkan oleh Yenrizal dan Izomiddin (2018), dalam strategi komunikasi politik pada perhelatan Pilwakot tahun 2018 lalu, pasangan HarnojoyoFitriani (dan sekarang Walikota Palembang) banyak berkaitan dengan isu lingkungan.

\section{Proses dalam Menyediakan Ruang Terbuka Hijau di Kota Palembang}

\section{Komunikasi}

Meskipun demikian realitas dan eksistensial yang terjadi, dalam menjawab ataupun setidaknya meminimalisir permasalahan penyediaan ruang terbuka hijau di kota Palembang, signifikansi langkah dalam menangani permasalahan tersebut telah ditetapkan dalam peraturan pemerintah daerah kota Palembang Nomor 15 Tahun 2012 (2012-2030) tentang Ruang Terbuka dan Ruang Wilayah (RTRW). Bahkan 
tingkat keseriusan pemerintah Kota Palembang terlihat secara jelas dari pondasi visi-misi Walikota Palembang. Namun, sampai saat ini belum mampu mewujudkan sebuah lahan yang berkomponen dan berbasis ruang terbuka, nyaman, produktif dan berkelanjutan. Karena prioritas pembangunan berkonsep ruang terbuka hijau hanya berkisar 10-11\%, dan bahkan terjadwal dalam tahun anggaran (TA) 2020 (Lenterapendidikan.com 2019).

Keberhasilan setiap implementasi kebijakan sangat tergantung pada pola dan bentuk komunikasi yang dibangun. Dalam aspek itu, penyampaian informasi harus disampaikan secara baik, jelas dan kosisten guna tercapainya dan terimplementasinya kebijakan yang efektif. Proses transmisi informasi juga sangat penting, terutama baik kepada pihak implementator maupun kepada publik.

Sebagaimana yang disampaikan oleh salah satu informan bahwa:

"informasi mengenai kebijakan penyediaan ruang terbuka hijau telah disampaikan melalui rapat dengan penjabat terkait. Berbagai hal berkaitan dengan teknis pelaksanaan telah dipahami semua pihak yang terlibat, dan juga telah memahami mengenai tanggung jawab melalui pelatihan-pelatihan, penyuluhan dan pembinaan".

Hal tersebut senada dengan penjelasan oleh Harry Emirza, SP (25/06/2020) yang mengatakan bahwa

"Sosialisasi kepada masyarakat (pengunjung taman) pun telah dilaksanakan dengan baik, dan secara simultan dengan tujuan agar dalam kerjasama dalam menyukseskan kebijakan tersebut".

Berdasarkan hasil wawancara diatas, penyampaian informasi dan sosialisasi mengenai kebijakan penyediaan ruang terbuka hijau di Kota Palembang, telah dilaksanakan oleh pihak implementor dalam bentuk penyuluhan, pelatihan dan pembinaan. Dengan demikian, faktor komunikasi dalam aspek penyampaian subtansialitas kebijakan mulai dari pihak pelaksana, dinas pertamanan dan seksi penghijauan telah berjalan cukup maksimal.

\section{Sumber daya}

Sumber daya manusia merupakan salah satu variabel penting yang dapat mempengaruhi keberhasilan maupun kegagalan setiap kebijakan. Hal tersebut sangat bergantung kepada sumber daya manusia (aparatur) dalam aspek keahlian dan kemampuan yang mumpuni dalam melaksanakan tugas. Disamping itu, dukungan sumber daya anggaran, kewenangan dan sarana dan prasarana pun sangat penting dalam mengimplementasikan kebijakan. Oleh karena itu, ketersediaan pelaksana yang memadai serta dukungan berkompetensi staf secara otomatis mendorong keberhasilan kebijakan.

Pada aspek profesionalitas dan kompetensi bahwa para pelaksana telah dibekali berbagai keterampilan, keahlian dalam melakukan penyuluhan dan pendampingan baik kepada masyarakat maupun media massa karena telah mengikuti pelatihan-pelatihan sebelumnya. Disamping itu, penindakan dan pemberlakuan sanksi terhadap para pelanggar yang tidak mematuhi aturan akan ruang terbuka hijau, telah diatur secara komprehensif dalam draf kebijakan. Wewenang secara legal formil dalam menyelesaikan permasalahan telah disepakati melalui aturan standard operational system (SOP). Dengan demikian, para 
pelaksana memiliki otoritas dalam menyelesaikan masalah yang dihadapi sepanjang sesuai dengan aturan berlaku.

Kendatipun demikian, pada konteks di lapangan adalah bahwa para petugas lapangan masih belum memadai secara kuantitatif yang berakibat pada ketidakefektivan dalam menjaga, mengawasi dan menindaklanjuti para pelanggar". Sebagaimana yang dijelaskan oleh salah satu petugas pertamanan (26/06/2020) yang mengungkapkan bahwa,

"Petugas lapangan saat ini masih kurang, meskipun ada petugas lapangan tapi karena kurangnya pengawasan dari patroli yang dilakukan sehingga efektifitas waktu penjagaan tidak begitu maksimal dalam rangka untuk menjaga pelanggaran yang ada ditaman ini".

Kekurangan petugas tersebut diakui oleh salah satu pengunjung di salah satu taman kota, sebagaimana diungkapkan oleh informan (26/06/2020)

"Akibat dari itu kurangnya petugas di lapangan yang terjadi adalah masyarakat sering (pengunjung) melanggar, bahkan merusak fasilitas taman bahkan tidak memperdulikan peraturan yang ditetapkan".

Bertolak belakang dengan kekurangan staf di lapangan, permasalahan fasilitas berupa penyediaan sarana dan prasarana, berikut pemaparan Harry Emirza Triyudha (25/06/2020) sebagai Kepala Pembibitan pertamanan (DPRKP) Kota Palembang yang menyatakan bahwa:

"Dalam kebijakan ini dana yang disediakan oleh pemerintah masih kurang, sehingga bantuannya diberikan sesuai kebutuhan dari Bidang Pertamanan seperti fasilitas yang disediakan oleh pemerintah berupa pembangunan tempat pembibitan, pengadaan bibit, pengadaan pupuk, yang dimana kesemuanya ini dibiayai pemerintah dalam jumlah yang terjangkau".

Sejalan dengan itu, kurangnya dukungan pemerintah dalam menyediakan fasilitas baik berupa tempat pembibitan, pengadaan bibit, pengadaan pupuk masih belum memadai. Meskipun, dari aspek sarana dan prasarana operational telah memadai dan maksimal. Akan tetapi, jika fasilitas dan sarana prasarana operational masih belum maksimal akan mempengaruhi tingkat keefektivan kebijakan yang dtetapkan.

\section{Disposisi}

Disposisi merupakan aspek sangat penting yang berkaitan dengan sikap dan dukungan pihak implementator terhadap setiap program dan kebijakan. Dalam proses implementasi, sikap dan dukungan, dan kesamaan pandangan sangat penting karena memudahkan pencapaian tujuan. Begitupun sebaliknya, jika para pelaksana memiliki perbedaan sikap dan dukungan secara otomatis suatu kebijakan tidak akan tercapai secara efektif dan efisien. Salah satu dalam aspek tersebut dengan penempatan pegawai dan para pelaksana sesuai dengan spesialisasi dan kompetensi. Sebagaimana diungkapan oleh Herry Emirza (25/06/2020) bahwa,

"Saya rasa sudah tepat, para pelaksana ditempatkan sesuai dengan keahlian masing-masing karena mereka semua telah mengikuti pelatihan-pelatihan yang diselenggarakan oleh pihak Dinas Pertamanan”. 
Selain itu, dalam hal penempatan posisi para pegawai ditambahkan pula oleh Anita Fitro selaku Staf Bidang Pertamanan (25/06/2020) mengatakan bahwa

"Para pelaksana perda ini sudah sangat mengerti apa isi dan tujuan kebijakan penyediaan ruang terbuka hijau publik ini karena mereka telah melakukan pelatihanpelatihan yang dibiayai langsung oleh pemerintah, jadi mereka sudah paham maksud dari kebijakan ini, penempatan pegawai saya rasa sudah sangat tepat sesuai bidang dan spesialisasi kerja masing-masing".

Signifikansi terhadap permasaan prinsip, pandangan sangat penting untuk ditekankan pada kebijakan yang sedang diimplementasikan, yang berdampak langsung pada konsistensi dan potensi para instrumental dalam melaksanakan kebijakan. Dalam konteks kebijakan dalam penyediaan ruang terbuka hijau di Kota Palembang, kesamaan gerak, sikap dan dukungan telah dilaksanakan semasa pelatihan, penyuluhan dan pembinaan terhadap penempatan pegawai, dan petugas lapangan dengan dengan keahlian dan spesialisasi masing-masing. Oleh karena itu, para pelaksana telah mengerti dan memahami tujuan subtansialitas dari kebijakan penyediaan ruang terbuka hijau publik tersebut. Dengan demikian, penempatan pegawai telah memadai, dengan keahlian dan spesialisasi yang diperkuat dalam berbagai macam pelatihan guna mengimpelementasikan kebijakan sehingga pelaksanaan program berjalan efektif.

\section{Struruktur Birokrasi}

Berkaitan dengan struktur birokrasi, mencakup dalam dua aspek. Pertama, mekanisme. Kedua, struktur organisasi pelaksana. Pada umumnya, mekanisme implementasi setiap kebijakan telah ditetapkan dalam konsep standard operating procedure (SOP) sebagai pemandu (guideline) program atau kebijakan.

Dalam konteks penyediaan ruang terbuka hijau di Kota Palembang, pada aspek struktur organisasi pada SKPD telah dilakukan begitu efektif, terhadap pembagian kerja, kewenangan, dan tanggung jawab masing-masing yang disesuaikan pada tugas pokok dan fungsinya supaya tidak terjadi tumpang tindih pelaksanaan implementasi kebijakan. Sebagaimana yang dijelaskan oleh informan (25/20/2020) mengatakan bahwa

"struktur organisasi pada SKPD terkait sudah cukup efektif, karena sudah dilakukan pembagian kerja sesuai dengan bidangnya dan tidak ada tugas yang seolah-olah tumpang tindih. Selain itu, garis kewenangan atau rentang kendali juga tidak jauh antara atasan dan bawahan".

Berdasarkan hasil analisis keseluruhan dapat disimpulkan bahwa struktur birokrasi/organisasi yang ada pada dinas PRKP khususnya bidang pertamanan kota Palembang sudah cukup jelas sesuai dengan peraturan sehingga diharapkan kebijakan tentang penyediaan ruang terbuka hijau publik dapat terlaksana dengan maksimal.

\section{KESIMPULAN}

Penyediaan ruang terbuka hijau di kota Palembang belum sepenuhnya maksimal. Meskipun demikian, pemerintah kota Palembang masih terus mengupayakan dalam mencapai aturan standar minimal $30 \%$ dari aturan yang telah ditetapkan. 
Implementasi kebijakan tersebut di bidang teknik telah menunjukkan kemajuan yang telah dibebankan kepada dinas perumahan rakyat dan kawasan pemukiman dalam melaksanakan kebijakan atau program tersebut.

Kendatipun demikian, upaya pengoptimalan kebijakan tersebut dapat tercapai, jika pemerintah kota Palembang lebih mempertegas dalam menindaklanjuti para pelanggar konversi lahan, bersinegeri dengan para pemangku kepentingan, peran dan partisipasi masyarakat. Dengan demikian, bukan hanya dapat mewujudkan aturan standar pemerintah, akan tetapi dalam menciptakan utopisme pemerintah kota Palembang dalam mewujudkan pembangunan infrastruktur perkotaan yang terpadu, merata berkeadilan, berkelanjutan dan berwawasan lingkungan yang berbasis teknologi dan informasi.

\section{DAFTAR PUSTAKA}

Badan Pusat Statistik Palembang. 2018. "Data Penduduk Kota Palembang." https://www.bps.go.id/.

Bappena, BPS dan UNFPA. 2013. Bps Proyeksi Penduduk Indonesia 2010-2035. Jakarta.

Dwihatmojo, Roswidyatmoko. 2010. "Ruang Terbuka Hijau Yang Semakin Terpinggirkan." Badan Informasi Geospasial.

Edwards, George C. III. 1980. Implementing Public Policy. Washington: Congressional Quaterly Press.

Heidt, Volker, and Marco Neef. 2007. "Benefits of Urban Green Space for Improving Urban Climate." Ecology, Planning, and Management of Urban Forests: 84-96.

jdih.palembang.go.id. 2018. "Visi Misi." https://jdih.palembang.go.id/?judul=visi-danmisi\&nmodul=halaman (February 20, 2021).

Joga, Nirwono. 2013. RTH 30 Persen Resolusi Kota Hijau. Gramedia Pustaka Utama.

Lenterapendidikan.com. 2019. "Pemkot Palembang Prioritaskan Penambahan RTH.” Lenterapendidikan.con.

http://www.lenterapendidikan.com/berita/palembang/view/pemkot-palembangprioritaskan-penambahan-rth.html.

Miranti, Meidian et al. 2011. "Faktor-Faktor Yang Mempengaruhi Implementasi Kebijakan Ruang Terbuka Hijau Di Kabupaten Rembang." (1): 1-11.

Mogabay.co.id. 2014. "Ketika Rawa Dan Sungai Di Palembang Makin Kritis." https://www.mongabay.co.id/2014/02/13/ketika-rawa-dan-sungai-di-palembangmakin-kritis/ (February 20, 2021).

_. 2018. "Palembang Banjir, Tidak Mengejutkan. Apa Yang Harus Diperbaiki?" https://www.mongabay.co.id/2018/11/16/palembang-banjir-tidak-mengejutkanapa-yang-harus-diperbaiki/ (February 20, 2021).

Prakoso, Panji, and Herdis Herdiansyah. 2019. "Analisis Implementasi 30\% Ruang Terbuka Hijau Di Dki Jakarta." Majalah IImiah Globe 21(1): 17.

Rakhmatsyah, Asrul, Muhajirah Hasanuddin, and Muhammad Tahir. 2015. "Dampak Kebijakan Ruang Terbuka Hijau Di Kota Makassar." Administrasi Publik 1(2): 126-38.

Rijal syamsu. 2017. "Kebutuhan Ruang Terbuka Hijau Di Kota Makassar." Jurnal HUtan dan Masyarakat III(April 2008): 65-77.

Sary, Reny Kartika, and Erfan M Kamil. 2017. "Analisis Kebutuhan Ruang Terbuka 
Hijau Di Komplek Perumahan Kencana Damai Palembang Analysis of Green Space in Kencana Damai Residential Palembang." Jurnal Arsir 1(2): 150-60.

Sholihah, Imas, and Muslim Sabarisman. 2018. "Pemenuhan Kesejahteraan Sosial Melalui Optimalisasi Ruang Terbuka Hijau (Rth) Di Kawasaan Perkotaan Dalam Perspektif Hukum Dan Kebijakan." Sosio Informa 4(1): 297-312.

Suweda, I Wayah. 2011. "PENATAAN RUANG PERKOTAAN YANG BERKELANJUTAN, BERDAYA SAING DAN BEROTONOMI." IImiah Teknik Sipil 15(2): 93-98.

Syahrul Ansari dan Sadam Maulana. 2018. "Palembang Jadi Kota Paling Berkembang Di Indonesia." viva.co.id. https://www.viva.co.id/berita/nasional/1032783-palembang-jadi-kota-palingberkembang-di-indonesia (February 20, 2021).

Walhisumsel.com. 2010. "Palembang Minim RTH." Walhisumselblogspot.com. https://walhi-sumsel.blogspot.com/2010/02/palembang-minim-rth.html.

Walikota Palembang. 2012. "Rtrw Kota Palembang Tahun 2012-2032."

Yenrizal dan Izomiddin. 2018. "Strategi Komunikasi Politik Berbasis Isu Lingkungan Pada Pemilihan Umum Kepala Daerah Palembang 2018." Konferensi Perkumpulan Dekan IImu-IImu Sosial: 1-19.

Yusmawar. 2016. "Manfaat Ruang Terbuka Hijau Bagi Masyarakat Perkotaan Ditinjau Dari Aspek Sosial Ekonomi Kota Banda Aceh." Jurnal IImiah Mahasiswa (JIM) Ekonomi Pembangunan Fakultas Ekonomi dan Bisnis Unsyiah 1(1): 29098. 